\title{
Posterior Reversible Encephalopathy Syndrome in Two Patients with Severe Preeclampsia
}

\section{Şiddetli Preeklampsi Geçiren İki Hastada Posterior Reversible Ensefalopati Sendromu}

\section{(D) Murat Doğan1, (D) Sema Baghaki2, (D) Yasemin Tekdos¹, (D Keziban Doğan²}

${ }^{1}$ University of Health Sciences Turkey, Bakırköy Dr. Sadi Konuk Research and Training Hospital, Clinic of Anesthesiology and Reanimation, İstanbul, Turkey ${ }^{2}$ University of Health Sciences Turkey, Bakırköy Dr. Sadi Konuk Research and Training Hospital, Clinic of Obstetrics and Gynecology, İstanbul, Turkey

\section{Abstract}

Posterior reversible encephalopathy syndrome (PRES) is an entity that occurs due to vasogenic brain edema in predominantly posterior sections of the brain and is characterized by headache, altered mental status, vision loss or seizures. In this report, we present two women who developed PRES secondary to severe hypertension in pregnancy. Our goal is to outline the clinical features of the disease, diagnostic methods, management, and maternal outcomes. The etiology of PRES may vary in a wide range including hypertension, kidney failure, preeclampsia/ eclampsia, collagen vascular diseases, and sepsis. Prompt recognition and treatment of the syndrome after severe preeclampsia or eclampsia have major importance in order to prevent permanent damage to the brain.

Keywords: Eclampsia, hypertension, preeclampsia, posterior reversible encephalopathy syndrome

\section{Öz}

Posterior reversibl ensefalopati sendromu (PRES), başağrısı, mental instabilite, görme kaybı, nöbetler ile karakterize, ağırlıkı olarak beynin başta oksipital lob olmak üzere posterior kısımlarını tutan vazojenik ödem durumudur. Etiyoloji hipertansiyon, böbrek yetmezliği, kollajen vasküler hastalıklar, sepsis, preeklampsi/eklampsi gibi durumları içeren geniş bir yelpazede olabilir. Beyinde kalıcı hasarı önlemek icin erken teşhis ve hızı yönetim esastır. Bu olgu bildiriminde, sezaryenden 2 gün sonra şiddetli preeklampsi ve ardından HELLP sendromuna ilerleyen bir postpartum hasta ile eklampsi geçiren bir başka postpartum hastamızda gelişen PRES sendromunu ele almaktayız. Amacımız, PRES'nin klinik özelliklerini, diagnostik metodları, yönetimi ve maternal sonuçlarını ortaya koymaktır.

Anahtar kelimeler: Hipertansiyon, preeklampsi, eklampsi, posterior reversibl ensefalopati sendromu

\section{Introduction}

Posterior reversible encephalopathy syndrome (PRES) was first described by Hinchey et al. (1). PRES has become a more recognized medical term due to alerting neurologic symptoms. There are readily available imaging techniques that enable clinicians to make the diagnosis. It is characterized by headaches, seizures, nausea or vomiting, vision problems due to posterior cerebral white matter edema but the syndrome is not always reversible, and it is often not confined to either the white matter or the posterior regions of the brain $(2,3)$. The incidence of PRES is not known. The etiology of those disturbances may vary in a wide range including hypertension, kidney failure, preeclampsia/ eclampsia, collagen vascular diseases, sepsis, consumption of immunosuppressive agents, etc. It is more common in women even when patients with eclampsia are excluded (13). As definition, preeclampsia is a systemic vascular disorder characterized by new-onset hypertension and proteinuria after 20 weeks of gestation and eclampsia is defined as a seizure occurring in association with preeclampsia (4).

Address for Correspondence: Sema Baghaki, University of Health Sciences Turkey, Bakırköy Dr. Sadi Konuk Research and Training Hospital, Clinic of Obstetrics and Gynecology, İstanbul, Turkey

E-mail: semabaghaki@hotmail.com ORCID ID: orcid.org/0000-0003-3981-6069 Received: 30.06.2020 Accepted: 03.09.2020

Cite this article as: Doğan M, Baghaki S, Tekdos Y, Doğan K. Posterior Reversible Encephalopathy Syndrome in Two Patients with Severe Preeclampsia. Bagcilar Med Bull 2020;5(4):224-228

${ }^{\odot}$ Copyright 2020 by the Health Sciences University Turkey, Bagcilar Training and Research Hospital Bagcilar Medical Bulletin published by Galenos Publishing House. 
Prompt recognition and treatment of the syndrome are important in the prevention of the permanent damage that can occur in this otherwise typically reversible condition. The management of PRES is mostly based on the investigation and resolution of the underlying cause. If the underlying cause is diagnosed and treated effectively, clinical symptoms may subside in a week $(1,2)$.

There are a few theories to explain the pathophysiology of PRES. The most popular theory is that the autoregulation of the blood perfusion in brain vessels is disrupted due to uncontrolled hypertension (2). Sudden elevations in blood pressure cause the extravasation of proteins to the intercellular area and this results in vasogenic edema. However, this theory does not explain the cerebral hypoperfusion which can sometimes be seen in PRES and why PRES may occur in normotensive patients as well. In this perspective, the association of PRES with systemic inflammatory conditions such as autoimmune diseases, sepsis or preeclampsia has revealed a theory which claims that PRES might be associated with endothelial dysfunction (5). Compatible with both theories, the pathogenesis of preeclampsia or eclampsia makes a predisposition to developing PRES syndrome. Therefore, it is a potentially devastating disease for which obstetricians should be prepared in preeclamptic pregnant women.

In these case presentations, we aimed to present two preeclamptic women who recovered without any sequela in intensive care unit (ICU) after developing PRES. Both of patients provided informed consents regarding their medical information to be used in this study. With this article, we would like to show the importance of early diagnosis and optimal management of the entity.

\section{Case Reports}

\section{Case 1}

A 32-year-old primigravida woman was admitted at 35 weeks of gestation due to hypertension of $170 / 100 \mathrm{mmHg}$. Her hemoglobin level, hematocrit, white blood cell count and platelet level were $9.6 \mathrm{~g} / \mathrm{dL}, 32 \%, 9.25 \times 10^{3} / \mu \mathrm{L}$ and 155 $10^{3} / \mu \mathrm{L}$, respectively. Her liver function enzymes, namely aspartate aminotransferase (AST), alanine aminotransferase (ALT), were 47 and $35 \mathrm{U} / \mathrm{L}$. She had +1 proteinuria in urine analysis and her fundoscopic examination was in normal limits without having any sign of intracranial hypertension. Her high blood pressure was taken under control with 250 mg of alpha methyl dopa per 6 hours. The intrauterine growth retardation was detected in fetus according to ultrasonographic measurements which were consistently indicating 31 weeks of gestation. Betamethasone injections were applied in order to support the pulmonary function. During her prenatal care, late decelerations resistant to resuscitations occurred and she underwent an urgent cesarean section due to the diagnosis of fetal distress. She did not have any complications in postoperative 48 hours. At day 3, her blood pressure raised to $180 / 110 \mathrm{mmHg}$ and subsequent generalized seizure with urinary incontinence occurred. Parenteral magnesium sulfate and glyceryl trinitrate infusion were promptly started. Urgent neurology, internal medicine, and anesthesia consultations were done. $4 \mathrm{mg}$ steroid injection for twice per day, metabolic panel, fibrinogen, and peripheral blood smear were ordered. Liver enzymes came up to be elevated 10 times (AST: $562 \mathrm{U} / \mathrm{L}$, ALT: $199 \mathrm{U} / \mathrm{L}$ ), fibrinogen level was found to be slightly low $(198 \mathrm{mg} / \mathrm{dL})$ and platelet counts suddenly decreased to $44.00010^{3} / \mu \mathrm{L}$. In the peripheral blood smear, the hematologist found too many acanthocytes to count and the actual platelet number was $34.00010^{3} / \mu \mathrm{L}$. HELLP syndrome was diagnosed and the patient was transferred to ICU. One volume of plasmapheresis was planned. Meanwhile, she became sluggish and her consciousness gradually deteriorated. She was not opening eye neither to verbal command nor to pain. Her Glasgow Coma score was 6 (one for no eye-opening, one for no verbal response and 4 for withdrawal from pain). Urgent cranial magnetic resonance imaging (MRI) and MRI venography were carried out. Diffuse high signal intensity on T2-weighted (Figure 1) and fluid-attenuated inversion recovery (Figure 2) images were interpreted to be edematous lesions located in the cerebellum and through the temporoparietal junction to the cortex of the brain. The lesions were found to be compatible

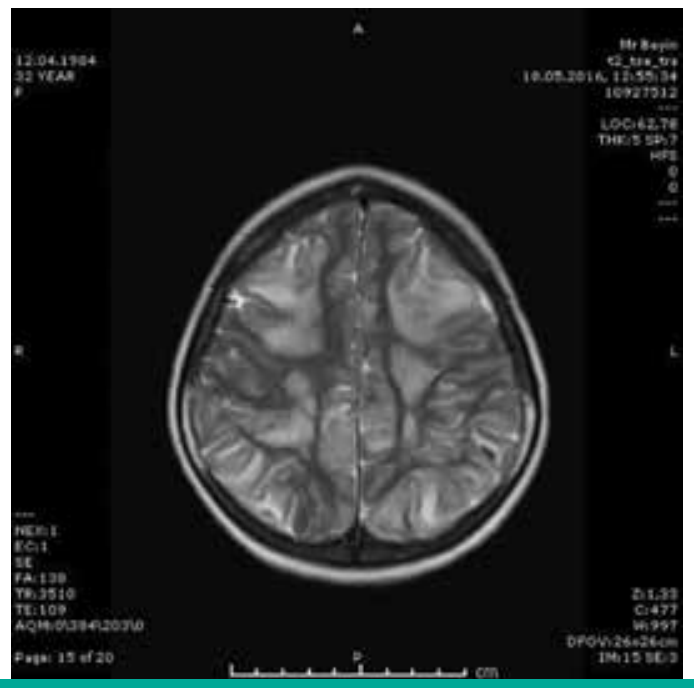

Figure 1. Hypointense lesions on T2- weighted sections 
with PRES. 200 cc Mannitol IV push was administered to decrease extracellular fluid retention in the brain. Close observation was undertaken with an intermittent metabolic panel and coagulation markers. After the completion of plasmapheresis, prednol $1 \mathrm{mg} /$ day per kilogram was ordered. Her liver enzymes and coagulation markers were gradually normalized. With the anti-edematous and supportive treatment, patient clinically improved in 3 days and she was out of ICU on the postoperative day 8. After spending 3 days in inpatient service for full recovery, she was discharged to home.

\section{Case 2}

A 28-year-old nulliparous woman was admitted for the diagnosis of preeclampsia and in-utero growth restriction at the gestational age of 28 weeks and 1 day pregnancy.

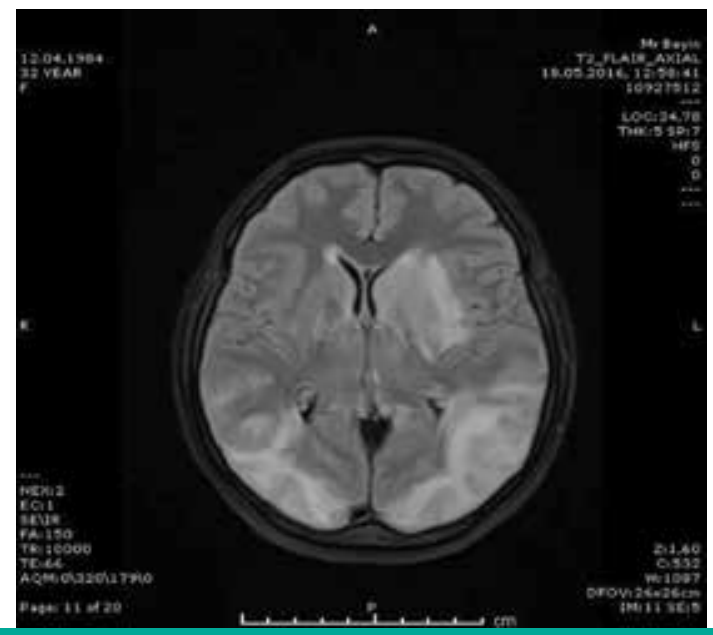

Figure 2. Hypointense lesions on FLAIR sections FLAIR: Fluid-attenuated inversion recovery

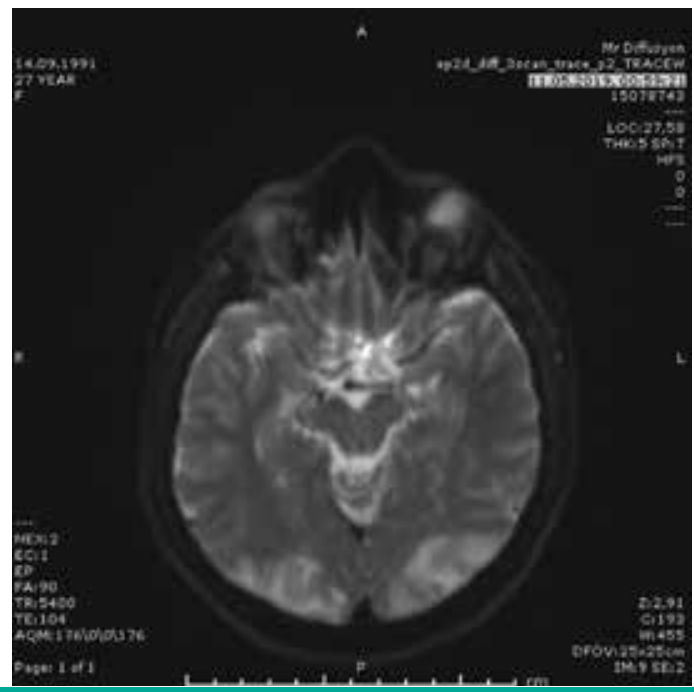

Figure 3. Hyperintense lesions on diffusion-weighted MRI MRI: Magnetic resonance imaging
Her initial blood pressure was 150/110 $\mathrm{mmHg}$ and there was +3 protein in urine analysis. Abdominal circumference of fetus was in the $3^{\text {rd }}$ percentile and there were notches in the bilateral uterine arteries. Her initial liver function enzymes were in the normal limits (ALT: 21, AST: $20 \mathrm{U} / \mathrm{L}$ ), platelet count was $175,00010^{3} / \mu \mathrm{L}$ and proteinuria in 24 hour urine was $9.149 \mathrm{mg}$. Two consequent doses of $12 \mathrm{mg}$ betamethasone injections were applied for pulmonary maturation. As severe preeclampsia was diagnosed, antihypertensive treatment and $2 \mathrm{gr} / \mathrm{h}$ of magnesium sulfate infusion were started. She was taken to the close observation of perinatalogist. At the $4^{\text {th }}$ day of hospitalization, the doppler examination of umbilical arteries were normal but there was minimal ascites in the maternal abdomen. By day 5 , she developed prodromal findings such as generalized headache and scotomas in the visual field and the blood pressure elevated once again to $170 / 90 \mathrm{mmHg}$, she underwent urgent $\mathrm{C}$-section. There were no complications during or the first 24 hours of surgery. After that, her blood pressure peaked and she developed diplopia. Once the blood pressure was stabilized after the increase in the dose of antihypertensive treatment, the diplopia was regressed. However, on the postoperative day 2, she developed a generalized tonic-clonic seizure, her blood pressure reached to $200 / 110 \mathrm{mmHg}$, pulse was 98 and oxygen saturation was $91 \%$. Airway was applied immediately, oxygen flow was started at the rate of $10 \mathrm{Lt} / \mathrm{min}$. She was protected from the sharp edges at the surrounding and bilateral IV routes were inserted. Loading dose of magnesium sulfate and $5 \mathrm{mg}$ of hydralazine sulfate were pushed. The blood pressure regressed to $180 / 90 \mathrm{mmHg}$ and the seizure came to the end. She had stabilized as the anticonvulsant therapy was started. Shortly after, she was consulted to neurology because of persistent hypertension, lethargy, generalized headaches and diplopia. Computerized tomography (CT) scan was performed and her fundoscopic examination results were found to be in normal limits with no signs of papilledema or findings of hypertensive retinopathy. Since her cranial CT showed a hypodense lesion at the site of posterior cerebral artery (PCA), diffusion MRI was ordered immediately in order to investigate PRES syndrome related to eclampsia or other differential diagnoses. MRI showed hyperintensity (Figure 3) in the perfusion area of PCA, which was found to be compatible with PRES syndrome. Mannitol $100 \mathrm{mg} 4 \mathrm{xl}$ and dexamethasone 2x8 mg infusions were started per neurology consultation. Because of persistent hypertension, lethargy and diplopia for more than 6 hours, she was transferred to ICU for the monitorization of mental status and vitals. The persistent hyperintensive lesions in 
the left occipital and bilateral frontal lobes in the second cranial MRI confirmed the vasogenic edema due to PRES. The antihypertensive treatment, levatiracetam 3x500 mg, furosemide $2 \times 40 \mathrm{mg}$ and sedative agents were administered in ICU. As she was extubated and neurologic examination was normal, she was transferred back to inpatient service on the postoperative day 8 .

\section{Discussion}

In our cases, PRES syndrome most possibly occurred secondary to late postpartum eclampsia (LPE). In LPE, the seizures are seen 2 days to 4 weeks after the delivery. LPE can be challenging to diagnose since those pregnant women may not have obvious findings of preeclampsia such as high blood pressure or proteinuria but both of those patients had an obvious preeclampsia presentation.

Preeclampsia is attributed to generalized endothelial dysfunction of the vessels due to the cytotoxic trophoblastic factors that originated from the placenta. It is still unknown if this damage in the endothelial lining is the cause or the result of hypertension. In both situations, the blood-brain barrier disruption causes fluid and protein transudation to the intercellular area, and this may lead to brain edema. Also, the cerebral autoregulation of blood perfusion cannot be sustained after repetitive abrupt hypertensive changes in brain blood vessels and this situation further increases the interstitial fluid and exacerbates vasogenic edema $(6,7)$. This mechanism also explains the possible pathogenesis of seizures seen in our patients.

As the name indicates, the lesions of PRES are generally located in the posterior territory of the brain. This is thought to be secondary to decreased sympathetic innervations around the basilar artery and its branches. The classic response of arterioles to hypertension is vasoconstriction in order to limit hyperperfusion and possible extravasation of plasma. This response is regulated by sympathetic nerves and the posterior regions that have relatively scarce sympathetic innervations become more prone to develop vasogenic edema (8).

Although the relationship between PRES and preeclampsia/ eclampsia has not been clearly explained, we believe that the trophoblastic cytokines cause generalized endothelial dysfunction and play a major role in the development of PRES similar to our cases with preeclampsia and eclampsia (5).

The management of PRES should be based on the underlying pathology. In our cases, the definitive treatment of preeclampsia, which is the delivery of the baby, was already carried out. Prompt blood pressure control and regulation of electrolyte disturbances are the mainstays of treatment. To decrease the cerebral edema and prevent convulsions, we administered anti-edematous medications such as mannitol and steroids (methylprednisolone/ dexamethasone). Anti-convulsive agents are also suggested for symptomatic treatment.

\section{Conclusion}

PRES should always be considered as one of the differential diagnosis in preeclamptic or eclamptic women who present with altered mental status, convulsions or headaches. Prompt diagnosis and treatment of underlying cause will likely expedite the resolution of cerebral edema and full recovery is expected in days to weeks.

\section{Ethics}

Informed Consent: All forms of consent are available to share the patient's photos and data after surgery.

Peer-review: Externally peer-reviewed.

\section{Authorship Contributions}

Concept: M.D., K.D., Design: M.D., K.D., Data Collection or Processing: S.B., Analysis or Interpretation: Y.T., Writing: S.B.

Conflict of Interest: The authors declare that there is no conflict of interest with regard to this manuscript.

Financial Disclosure: No financial support was received from a person or a company for writing this case report.

\section{References}

1. Hinchey J, Chaves C, Appignani B, Breen J, Pao L, Wang A, et al. A reversible posterior leukoencephalopathy syndrome. N Engl J Med 1996;334:494-500.

2. Roth C, Ferbert A. The posterior reversible encephalopathy syndrome: what's certain, what's new? Pract Neurol 2011;11(3):136144.

3. McKinney AM, Short J, Truwit CL, McKinney ZJ, Kozak OS, SantaCruz KS, et al. Posterior reversible encephalopathy syndrome: incidence of atypical regions of involve $\neg$ ment and imaging findings. AJR Am J Roentgenol 2007;189(4):904-912.

4. The Eclampsia Trial Collaborative Group. Which anticonvulsant for women with eclampsia? Evidence from the collaborative eclampsia trial. Lancet 1995;345:1455-1463.

5. Bartynski WS. Posterior reversible encephalopathy syndrome, part 2: controversies surrounding pathophysiology of vasogenic edema. AJNR 2008;29(6):1043-1049.

6. Schwartz RB, Feske SK, Polak JF, DeGirolami U, Iaia A, Beckner KM, et al. Preeclampsia-eclampsia: clinical and neuroradiographic 
correlates and insights into the pathogenesis of hypertensive encephalopathy. Radiology 2000;217(2):371-376.

7. Savvidou MD, Hingorani AD, Tsikas D, Frölich JC, Vallance P, Nicolaides KH. Endothelial dysfunction and raised plasma concentrations of asymmetric dimethylarginine in pregnant women who subsequently develop pre-eclampsia. Lancet 2003;361(9368):1511-1517.

8. Bartynski WS. Posterior reversible encephalopathy syndrome, Part 1: Fundamental imaging and clinical features. AJNR 2008;29(6):1036-1042. 